\title{
Aralıklı Açlık Diyetleri ve Düşük Karbonhidratlı Diyetlerin Obezite Tedavisindeki Etkisi
}

\author{
The Effect of Intermittent Fasting Diets and Low Carbohydrate Diets on Obesity Treatment
}

\author{
Gökçe Sueda Aydoğdu'1 , Gamze Akbulut ${ }^{2}$
}

Geliş tarihi/Received: 26.02.2020 • Kabul tarihi/Accepted: 21.08.2020

\section{ÖZET}

Obezite, prevalansı giderek artan küresel bir sağlık sorunudur. Fazla kilolu ve obez bireyleri tedavi etmek için yeni diyet stratejileri oluşturulmuştur ve bu diyet stratejileri popüler ve yaygın hale gelmiştir. Bu diyetler arasında "aralıklı açlık diyetleri” ve “düşük karbonhidratlı diyetler (DKD)” bulunmaktadır. Birçok aralıklı açlık diyeti varyasyonu açlık döngülerinin uzunluğu ve sıklığı bakımından farklılık gösterir. Alternatif gün açlık diyetleri (dönüşümlü açlık), zaman kısıtlı beslenme, dini oruç olarak sınıflandırılabilir. Düşük karbonhidratlı diyetlerin ortak bir tanımı bulunmamaktadır. Bazı DKD’lerde enerji alımına bağlı, bazılarında ise enerji alımından bağımsız olarak karbonhidrat alım miktarı kısıtlanmaktadır. Alternatif gün açlık diyetlerinin ve zaman sınırlı beslenmenin vücut ağırlığı kaybında olumlu etkileri olduğu öne sürülmektedir, ancak, açlık süresinin uzaması diyete uyumu azaltabilir. Ramazan orucunda ise genellikle bir aylık süreçte kaybedilen vücut ağırlığı geri kazanılmaktadır. Düşük karbonhidratlı diyetlerin vücut ağırlığı kaybı üzerine olumlu etkileri olsa da düşük yağlı diyetlerin etkileri konusunda çelişkili veriler bulunmaktadır. Her iki beslenme modeli de obezitede vücut ağırlık kontrolü için uygulanabilecek yaklaşımlar olabilir; ancak uzun dönemli etkilerinin ortaya konulması için uzun süreli takip çalışmalarına ihtiyaç duyulmaktadır.

Anahtar kelimeler: Aralıklı açllk diyetleri, düşük karbonhidratll diyetler, obezite

\begin{abstract}
Obesity is a global health problem with an increasing prevalence. New dietary strategies have been established to treat overweight and obese individuals, and these dietary strategies have become popular and widespread. These diets include "intermittent fasting diets" and "low-carb diets (LCD)". Many intermittent fasting diet variations differ in length and frequency of fasting cycles. Intermittent fasting diets can be classified as alternative day fasting diets (alternating fasting), time- restricted diet, religious fasting. There is no common definition of low-carb diets. In some LCDs, the amount of carbohydrate intake is restricted, depending on the energy intake and in others, regardless of the energy intake. It is suggested that alternative day-fasting diets and time-restricted diet have positive effects on body weight loss. However, prolonged fasting period may decrease compliance with diet. In the fasting of Ramadan, body weight that is generally lost in a month is regained. Although low-carb diets have positive effects on body weight loss, there are conflicting data on the effects of low-fat diets. Both diet models can be approaches that can be applied for weight control in obesity; however, longterm follow-up studies are needed to reveal its long-term effects.
\end{abstract}

Keywords: Intermittent fasting diets, low carbohydrate diets, obesity

1. İletişim/Correspondence: Gazi Üniversitesi, Sağllk Bilimleri Fakültesi, Beslenme ve Diyetetik Bölümü, Ankara, Türkiye

E-posta: aysueda32@gmail.com• • ㄴ https://orcid.org/0000-0001-6833-4224
2. Gazi Üniversitesi, Sağllk Bilimleri Fakültesi, Beslenme ve Diyetetik Bölümü, Ankara, Türkiye • $\odot$ https://orcid.org/0000-0003-0197-1573 


\section{GíRIŞ}

Obezite, prevalansı giderek artan küresel bir sağlık sorunudur. Obez olan hastalar, kardiyovasküler hastalık (KVH), gastrointestinal bozukluklar, tip 2 diyabet, eklem ve kas hastalıkları, solunum problemleri ve psikolojik sorunlar da dâhil olmak üzere bir dizi komorbidite gelişimi açısından büyük risk altındadırlar (1). Fazla kilolu ve obez bireyleri tedavi etmek için yeni beslenme tedavisi stratejileri oluşturulmuştur. $\mathrm{Bu}$ tedavi yöntemleri giderek popüler ve yaygın hale gelmektedir. Vücut ağırlığı kaybı için diyet stratejileri; makro besin ögesi bileşimi değişikliğine dayalı diyetler, belirli yiyecek veya içecek gruplarının kısıtlandığı diyetler ve zaman değişikliğine dayalı diyetler olarak üç ana başlık altında toplanabilir. Öğün zamanında değişikliğe dayalı olan "aralıklı açlık diyetleri" ve makro besin ögesinin kısıtlanmasina dayalı diyetlerden biri olan “düşük karbonhidratlı diyetler (DKD)" en yaygin uygulanan diyetler arasındadır (2). Aralıklı açlık (intermittent fasting-IF), normal beslenmeye alternatif olarak belirli bir süre yiyecek ve enerji içeren içeceklerden uzak durulmasını amaçlar. Aralıklı açlık diyetleri aç kalma süresi ve açlık sıklığı yönünden birbirinden farklıdır (3). Alternatif gün açlık diyetleri (alternative day fasting-ADF-) ve zaman kısıtlı beslenme (time-restricted feeding-TRF), IF diyeti çeşitlerindedir (2). Düşük karbonhidratlı diyetler, ilk kez 1869 yılında bir dönem William Banting Corpulence tarafından savunulmuş, 1972 tarihinde Dr. Atkins'in Diyet Devrimi başlıklı yayınından sonra popüler hale gelmiştir. Düşük karbonhidratlı diyetlerin kabul görmüş bir tanımı bulunmamaktadır (4). Bu derlemenin amacı, aralıklı açlık ve DKD’lerin obezitede vücut ağırlık kontrolü ve metabolik parametreler üzerine etkilerini incelemektir.

\section{ARALIKLI AÇLIK DIYYETLERI}

Aralıklı açlık diyetleri, vücut kompozisyonunu ve genel sağlı̆̆ı iyileştirmek için çeşitli açlık protokollerini kapsayan geniş bir terimdir (5). Birçok IF varyasyonu açlık döngülerinin uzunluğu ve sıklığı bakımından farklılık gösterir (3). Alternatif gün açlık diyetleri ve zaman kısıtlı beslenme (dini oruç) IF diyeti çeşitlerindedir (2).

Aralıklı açlık diyetlerinin (a) sirkadiyen biyolojisi, (b) bağırsak mikrobiyotası ve (c) değiştirilebilir yaşam tarzı davranışları üzerinde metabolik etkilerinin olabileceği varsayılmaktadır (6). Şekil 1'de, aralıklı açlık ve sağlık sonuçları arasındaki ilişkide etkili

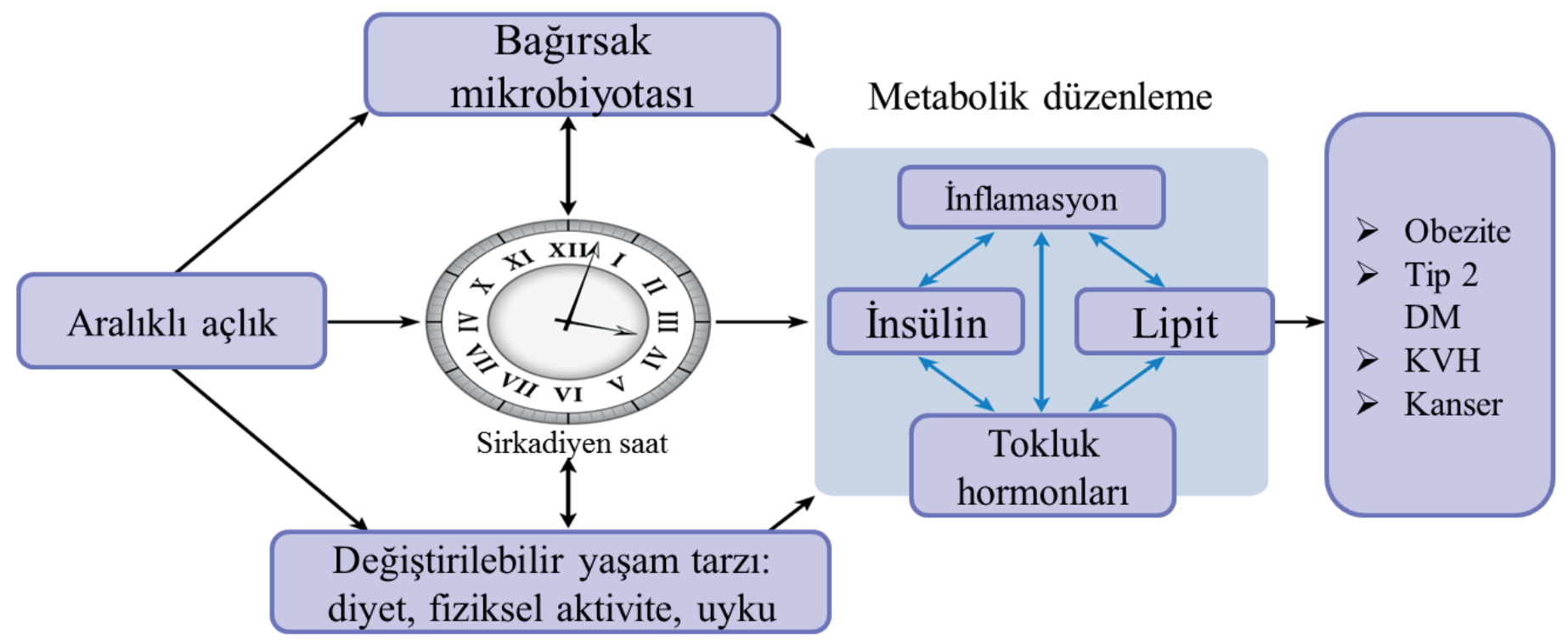

Şekil 1. Aralıklı açlık ve sağlık sonuçları arasındaki ilişkide etkili olan faktörler (6) KVH: Kardiyovasküler hastalık; Tip 2 DM: Tip 2 diyabet 
olan faktörler gösterilmektedir (6). Işık, melatonin, sıcaklık, uzun mesafeli uçak seyahatleri, vardiya değişimleri (7), öğünlerin tüketim zamanları arasındaki süre ve öğünlerin tüketildiği saatler sirkadiyen ritmi etkilemektedir (8). Bağırsak mikrobiyomu da metabolik sağlığı etkilemektedir. Mikrobiyomun çeşitliliği diyetle düzenlenmektedir ve besin sinyalleri tarafından düzenlenen sirkadiyen bir ritmi bulunmaktadır (6).

Yapılan bir çalışmada, vardiyalı çalışan bireylerin gündüz ve gece vardiyasındakibağırsakmikrobiyotası, beslenme durumu ve sirkadiyen ritimleri arasindaki ilişki değerlendirilmiştir. Bireylerden gündüz vardiyasında dört hafta çalıştıktan sonra ve gündüz vardiyasından gece vardiyasına geçtikten iki hafta sonra, fekal ve kan örnekleri alınmıştır. Çalışma sonunda, vardiyalı çalışmanın sirkadiyen ritim bozukluğu ile birlikte bağırsak mikrobiyotasında değişikliklere sebep olduğu gösterilmiştir. Ayrıca, gündüz vardiyasından gece vardiyasına geçildiğinde bağırsak mikrobiyotası, fekal kısa zincirli yağ asidi konsantrasyonu ve bazı biyokimyasal bulgulardaki değişimler nedeniyle bireylerin başta obezite olmak üzere çeşitli sağlık risklerine maruz kalabileceği sonucuna varılmıştır (9).

Beslenme, sirkadiyen ritmi (8) ve bağırsak mikrobiyotasını (6) etkilemektedir. Bununla birlikte sirkadiyen ritimdeki bozukluklar da bağırsak mikrobiyotasının değişmesine sebep olmaktadır (9).

\section{Alternatif Gün Açlık Diyeti}

Alternatif gün açlık diyetleri, açlık ve beslenme günlerinden oluşur. Açlık günlerinde hiçbir şekilde enerji içeriğine sahip besin ve içecek tüketilmemektedir. Diğer günler yani beslenme günlerinde ad libitum (isteğe bağlı) besin tüketimi sağlanmaktadır. Modifiye açlık diyetlerinde ise art arda olmayan iki gün planlanan açlık günlerinde, diyetle enerji alımı gereksiniminin \%20-25’i kadar olup geriye kalan beş gün ad libitum beslenmeyi içermektedir. Popüler 5:2 diyetlerinin temelini oluşturmaktadır. Popüler 5:2 diyeti haftada 2 gün birbirini izlemeyen günlerde enerji kısıtlamasını ve haftanın diğer 5 gününde sinırlandırılmamış yemeyi içermektedir (6). Alternatif gün açlık diyetlerinin hem vücut ağırlık kaybı hem de metabolik parametreler üzerine etkilerine yönelik çalışmalar bulunmaktadır $(5,10,11)$.

Trepanowski et al.'un (10) 2017 yllındaki çalışmasında, obez yetişkin bireyler, bir yıl süreyle üç gruba ayrılmıştır. Alternatif gün açlık grubu (ADF), açlık günlerinde enerji ihtiyaçlarının \%25'ini, beslenme günlerinde \%125'ini ve enerji kısıtlaması diyeti (calorie restriction-CR) grubu; her gün enerji ihtiyacının \%75’ini almıştır. Üçüncü grup kontrol grubu olarak ayrılmıştır. Katılımcılardan rutin aktivitelerini değiştirilmemeleri istenmiştir. Çalışma 6 ay süresince vücut ağırlığı kaybı aşamasından sonra, 6 ay süresince vücut ağırlığı koruma programını içermektedir. ADF grubunda, CR grubuna göre daha fazla katılımcı, diyete bağlı kalmanın zorlukları nedeniyle çalışmadan çekilmiştir. Altı ay sonunda toplam vücut ağırlığı kaybı ve 6 - 12 ay arasındaki vücut ağırlığı geri kazanımı, ADF grubu ile CR uygulanan grup arasında anlamlı farklılık göstermemiştir. Alternatif gün açlık diyetlerinin ve CR diyetlerinin uzun süreli etkileri karşılaştırıldığında her ikisinin de vücut ağırlık kaybına yol açtığı ancak birbirlerine bir üstünlüklerinin bulunmadığı belirlenmiştir.

Benzer bir çalışma Catenacci et al. (11) tarafından yürütülmüştür. Bu çalışmada, obez yetişkin bireyler ADF ve günlük CR (400 kkal/gün) olarak iki gruba randomize edilmiştir. Sekiz haftalık diyet uygulaması sonunda, vücut ağırlık değişiminde gruplar arasında farklılık gözlenmemiştir. Diyet uygulamasından sonraki 24 haftalık sürecin sonunda vücut ağırlığının geri kazanımında gruplar arasında anlamlı bir farklılık gözlenmemiştir. Sekizinci haftada, toplam kolesterol, HDL (yüksek dansiteli lipoprotein) ve LDL (düşük dansiteli lipoprotein) kolesterol seviyesi her iki grupta da anlamlı olarak azalmış, ancak gruplar arasında anlamlı bir farklılık olmadığı belirtilmiştir (11).

Bir derlemede, 3-12 haftalık süreçleri içeren ADF diyet uygulamaları incelenmiştir. Alternatif gün 
açlık diyetlerinin; normal kilolu, fazla kilolu ve obez bireylerde vücut ağırlığını, vücut yağ kütlesini, trigliserit, total ve LDL kolesterol düzeyini ve kan basıncını azaltmada etkili olduğu belirlenmiştir (5). İnsanlarda yürütülen 9 çalışmada modifiye açlık diyeti uygulaması incelenmiş, açlık müdahalelerinin süresinin 2-6 ay arasında değiştiği belirtilmiştir. Dokuz çalışmanın yedisi (\%78), istatistiksel olarak anlamlı vücut ağırlığı kaybı olduğunu bildirmiştir. Altı çalışmadan üçünde açlık insülininde önemli azalma, bir tanesinde de açlık glukozunda azalma bulunmuştur. Sekiz çalışmanın üçünde, dolaşımdaki LDL kolesterol veya trigliseritte önemli iyileşmeler belirlenmiştir (6).

Çalışmalarda ADF diyetinin, vücut ağırlığı ve metabolik (açlık glukozu, insülin, lipit düzeyleri) belirteçler üzerinde olumlu etkileri $(5,10,11)$ gözlense de ADF diyeti ile $\mathrm{CR}$ diyeti karşılaştırıldığında birbirlerine üstünlüğü belirlenmemiştir. Bu yüzden ADF diyeti CR diyetine alternatif olarak gösterilebilir $(10,11)$.

\section{Zaman Kısıtlı Beslenme}

Zaman kısıtlı beslenme (TRF-Time restricted feeding); tüm besin alımının her gün sekiz saat veya daha az bir zaman dilimi ile kısıtlandığı (12), besin kalitesini veya miktarını değiştirmeye yönelik bir girişimin olmadığı bir beslenme şeklidir (13). Zaman kısıtlı beslenme sirkadiyen saatleri etkileyerek metabolik düzenlemeyi sağlamaktadır (12). Zaman kısıtlı beslenmenin insan ve hayvanlarda hem vücut ağırlığı kaybı hem de metabolik parametreler üzerine etkilerini inceleyen çalışmalar bulunmaktadır (14-17).

Rothchild et al.'un (14) meta analiz çalışmasında; insanlar ve hayvanlarla yürütülen $3-4,7-8$ ve 10 12 saatlik TRF çalışmaları incelenmiştir. Hayvan çalışmalarından elde edilen sonuçlar TRF’nin; vücut ağırlığı, toplam kolesterol, trigliserid, glukoz, insülin, interlökin 6 (IL-6) ve tümör nekroz faktörü- $a$ (TNF-a) konsantrasyonlarındaki azalmaları ve insülin duyarlılığındakidüzelmeleriolumluyöndeetkilediğini belirlenmiştir. Çalışmada bu metabolik etkilerin, nedenleri tam olarak bilinmese de muhtemelen vücut ağırlık kaybından kaynaklandığı vurgulanmıştır. Zaman kısıtlı beslenmenin metabolik hastalık risk faktörleri üzerindeki etkileri, hayvan ve insan çalışmalarında benzerlik gösterirken vücut ağırlığı üzerindeki etkisinin farklı olduğu belirlenmiştir. Hayvan çalışmalarında 3-4 ve 8-9 saatlik TRF, insan çalışmalarında ise 10-12 saatlik TRF’nin vücut ağırlık kaybında daha etkili olduğu belirlenmiştir.

Başka bir çalışmada, postmenopozal obezite oluşturulan bir fare modelinde, yüksek yağlı bir diyete (\%60) ad libitum ulaşım veya sekiz saat sınırlı ulaşım (TRF) sağlanmıştır. Zaman kısıtlı beslenme uygulanan fareler, ad libitum beslenen fareler ile aynı yüksek yağlı diyete erişmesine rağmen, hızlı vücut ağırlığı kaybı yaşamıştır. Zaman kısıtlı beslenme uygulanan farelerde, insülin direncinde iyileşme ve hepatik steatoz şiddetinde azalma gözlenmiştir (15).

İnsanlar üzerinde yapılan TRF çalışmalarında ise gece boyunca kısıtlı beslenme (16) ve öğün atlama ile vücut ağırlığı kaybı araştırılmıştır (17). Normal vücut ağırlığına sahip 18-26 yaşları arasındaki 29 erkek birey üzerinde yapılan çapraz geçişli bir çalışmada katılımcılar; iki haftalık bir gece yeme kısıtlaması (19.00 - 06.00 saatleri arasında enerji alımının olmadığı) ve ardından iki haftalık kontrol aşamasına (günlük alışkanlıklarını ve yeme durumunu devam ettirdikleri) tabii tutulmuştur. Gece kısıtlı beslenme koşulu sırasında katılımcılar, kontrol koşulu sırasindakinden günlük daha az ortalama enerji ve daha az yağ tüketmişlerdir. Gece kısıtlı beslenme koşulunda ortalama vücut ağırlık değişiminin $(-0.4 \pm 1.1 \mathrm{~kg})$ kontrol aşamasına $(+0.6 \pm 0.9 \mathrm{~kg})$ göre anlamlı düzeyde fazla olduğu belirlenmiştir (16).

Randomize çapraz tasarlanan başka bir çalışmada, 24 obez birey, gece boyu açlıktan sonra ya kahvaltı tüketmemiş ya da karbonhidrat içeriği zengin olan 521 kkal enerji içeren bir kahvaltı tüketmişlerdir. Kahvaltıdan üç saat sonrasında katılımcılardan karbonhidrat içeriği zengin bir ad libutum öğle yemeği tüketmeleri istenmiştir. Öğle yemeği alımı, sabahları aç kalma süresinin uzamasından etkilenmemiştir. Öğle öğününde tüketilen besin miktarları benzer 
bulunmuştur. Bu çalışmayla obez yetişkinlerde, sabah açlıklarının uzamasının ad libitum bir öğle yemeğinde telafi edici alımlara neden olmadığı ve öğleden sonra iştahı artırmadığı gösterilmiştir (17).

Normal sirkadiyen beslenme döngüsünde, enerji alıminda kısıtlama olmadan sadece belirli bir zaman diliminde beslenmeye izin veren TRF, diyete uyumu artırabilir ve obezite ile ilişkili zararlı metabolik sonuçları azaltmak için bir yöntem sağlayabilir (15).

Enerji alımını kısitlamayan, zaman kısitlaması olan bir beslenme şekli de Ramazan orucudur. Bir ay boyunca ardışık olarak şafaktan gün batımına kadar aç kalınan bir beslenme modelidir. (18). İslami şartlarda oruç tutulurken su ve besinlerden uzak durulması gerekmektedir. Oruç tutanların bulundukları zaman dilimine bağlı olarak açlık süreleri (6-18 saat) değişmektedir (19). Sadeghirad et al.'un (20) 35 çalışmayı değerlendirdiği metaanaliz çalışmasında, Ramazan ayındaki vücut ağırlık değişimi incelenmiştir. Çalışmaların 21'inde (\%60) istatistiksel olarak anlamlı vücut ağırlığı kaybı belirlenmiştir. Bu meta analizde yer alan çalışmalarda, Ramazan ayı boyunca ortalama 1.24 kg vücut ağırlı̆̆ı kaybı gözlenmiştir. Meta analizdeki 16 takip çalışmasında, Ramazan ayını takip eden iki hafta boyunca ortalama $0.72 \mathrm{~kg}(0.32-1.13 \mathrm{~kg})$ vücut ağırlığı geri kazanılmıştır. Bu derlemenin sonucunda Ramazan ayında kaybedilen vücut ağırlığının nispeten küçük olduğu ve oruç sırasında vücut ağırlığındaki değişikliklerin çoğunlukla Ramazan öncesi durumuna geri döndügünü belirtilmiştir.

Ramazan orucunun vücut ağırlığı üzerine etkisiyle ilgili literatürde farklı sonuçlar belirtilmektedir. Yapılan bir çalışmada vücut ağırlığı, visseral yağ doku alanı, serum adipokin düzeyleri, diyet alımı ve fiziksel aktivite Ramazan ayının öncesinde ve sonunda değerlendirilmiştir. Çalışmaya hafif şişman ve obez bireyler dâhil edilmiştir. Ramazan ayı sonunda vücut ağırlığı, visseral yağ doku alanı, serum total kolesterol, trigliserit, HDL kolesterol, sistolik kan basıncı ölçümleri önemli düzeyde azalmıştır. Serum adiponektin, IL-6, TNF-a ve insülin benzeri büyüme faktörü-1 (IGF-1) seviyeleri de anlamlı derecede düşmüştür. Bununla birlikte serum visfatin, leptin, apelin, IL-10 ve IL-10/IL-6 oranı artmıştır (21).

Başka bir çalışmada tip 2 diyabetli bireylerde Ramazan orucunun glisemik kontrol, enerji alımı ve vücut kompozisyonu üzerine etkileri değerlendirilmiştir. $\mathrm{Bu}$ çalışmada hekim tarafindan oruç tutabileceği onaylanan 29 yetişkin birey $\geq 15$ gün boyunca oruç tutmuştur. Oruç sonunda HbA1c düzeyi önemli ölçüde iyileşmiştir. Vücut ağırlığında belirgin bir değişiklik olmamasına rağmen, vücut yağ kütlesinde düşük bir miktar fakat anlamlı bir azalma gözlemlenmiştir. Çok değişkenli analizlerde, HbA1c'deki azalmanın kısmen vücut yağ kütlesindeki azalmayla ilişkili olduğu belirlenmiştir (22).

Ramazan orucunda vücut ağırlığındaki değişimin sadece beslenme süresindeki ya da enerji alımındaki kısıtlamalardan dolayı açıklanamayacağı; dehidratasyon, diyetteki değişiklikler, fiziksel aktivite, uyku saatleri gibi farklı faktörlerin birleşiminin etkili olabileceği düşünülmektedir. Sirkadiyen ritim, tiroid fonksiyonları, serum kortizol düzeyleri, plazma leptin, adiponektin ve nöropeptid Y seviyeleri bu beslenme düzeninin yol açtığı metabolik ve hormonal değişikliklerdendir. Ramazan orucu modelinde kanda tiroid hormonları, nöropeptid Y düzeylerinin azaldığı, serum leptin, kortizol seviyelerinin ise arttığı belirtilmiştir. Açlığa yanıt olarak artan kortizol seviyelerinin insülin direncinde etkili olduğu gösterilmiştir (23). Ramazan orucu süresince gözlenen vücut ağırlığı kaybının, bu beslenme düzeninin son bulmasından kısa bir süre sonra tekrar kazanılma eğiliminde olduğu da belirtilmiştir (24). $\mathrm{Bu}$ çalışmaların açlık periyotlarının dünya üzerinde yaşanan coğrafi konuma ve mevsime göre değişiklik göstermesi kontrolün yeterince sağlanamamasına neden olmaktadır. Bunun yanı sıra sirkadiyen ritimde görülen olumsuz değişimler ve kronik hastalık durumlarında uygulanamaması, sürdürülebilirliğinin zor olması gibi durumlar bu beslenme modelinin vücut ağırlık kaybı için önerilebilirliğini ortadan kaldırmaktadır. Ramazan ayı vücut ağırlığı kaybı için bir firsat sağlamaktadır; ancak yaşam boyu vücut 
ağırlığı kaybının korunabilmesi için planlanmış (bütün olarak düşünülmüş) ve tutarlı yaşam tarzı değişikliği gerekmektedir.

Tüm bu diyetlerin vücut ağırlık kaybı üzerindeki etkileri özetlenecek olursa; düşük veya normal aralıkta kan glukoz düzeylerinin korunması, glikojen depolarının tükenmesi ya da azalması, yağ asitlerinin mobilizasyonu ve ketonların oluşumu, dolaşımdaki leptin düzeylerinin azalması ve adiponektin düzeylerinin yükselmesi gibi bazı temel metabolik değişikliklere yol açarak vücut ağırlık kaybına neden olduğu söylenebilir. Ancak, vücut ağırlık kaybını hedefleyen diyetler; fiziksel fonksiyonu sürdürmek, dinlenme metabolizma hızındaki düşüşü yavaşlatmak ve ağırlık kazanımını önlemek için vücut yağ kaybını maksimum düzeye çıkarmayı ve yağsız kütle kaybını minimum düzeye indirmeyi amaçlamaktadır. Aralıklı açlık diyetleri verilerinin yağsız vücut kütlesini korunumunu göstermek için yeterli etkiye sahip olmadığı söylenebilir.

\section{DÜŞÜK KARBONHİDRATLI DIYYTLER}

Düşük karbonhidratlı diyetler (DKD), ilk kez 1869 yllinda William Banting Corpulence tarafindan ortaya atılmıştır. Bu diyet modeli, 1972 tarihinde Dr. Atkins'in Diyet Devrimi kitabının yayınlanmasıyla popülerliğini yeniden kazanmıştır. Düşük karbonhidratlı diyetlerin tanımına yönelik bir fikir birliği yoktur. Bazı DKD’lerde enerji alımına bağlı, bazılarında ise enerji alımından bağımsız olarak karbonhidrat alım miktarı kısıtlanmaktadır (4). Tablo 1, düşük karbonhidratlı diyetler ve temel özelliklerini göstermektedir.

Vücut ağırlığı kaybı ve vücut ağırlığı yönetimi için düşük karbonhidratlı diyete olan ilgi artmaktadır. Bununla birlikte, düşük karbonhidratlı diyetler vücut ağırlığı kaybı amacıyla doğrudan önerilmemektedir. Çünkü düşük karbonhidratlı bir diyetin, KVH risk faktörleri üzerinde olumsuz etkilere sahip olacağına dair bir görüş vardır. Bunun nedeni vücut ağırlık kaybı sağlayan diğer diyetlere göre doymuş yağ asitleri içeriğinin daha yüksek olmasıdır (25).
Düşük karbonhidratlı diyetlerin dengeli bir zayıflama diyetine göre daha fazla vücut ağırlığı kaybını sağladığı öne sürülmektedir. Bu etkiye dair iki hipotez ortaya atılmıştır. Bunlardan biri proteinden gelen enerjinin daha fazla olduğu ve vücudun proteinleri metabolize etmek için daha fazla enerji (400-600 kkal) harcadığıdır. Diğer teori ise DKD’lerin yüksek protein içeriklerinden dolayı doygunluk hissi oluşturması, iştahı kontrol eden hormonlar üzerine etkisi ve keton cisimciklerinin iştahı baskılayıcı etkilerinden dolayı besin alımının azalmasıdır (26). Düşük karbonhidratlı diyetlerin vücut ağırlığı kaybına etkisini inceleyen çalışmalar bulunmaktadır $(27,28)$.

Bazzano et al. (27) randomize paralel grup çalışmasında, enerji kısıtlaması olmayan DKD $(<40$ g/gün) ve düşük yağlı diyeti (<\%30 yağ; $<\% 7$ doymuş yağ) karşılaştırmıştır. Düşük karbonhidratlı diyet grubundaki bireylerin düşük yağlı diyete göre 12 . ayda, vücut ağırlıklarında ortalama $3.5 \mathrm{~kg}$, yă kütlesinde $-\% 1.5 \mathrm{~kg}$ daha fazla azalma ve yağsız dokuda da artış olduğu gözlenmiştir ( $p<0.05)$. Düşük karbonhidratlı diyet grubunda HDL kolesterol ve trigliserit seviyelerinde az yağlı diyet grubuna göre anlamlı bir düşüş gerçekleşmiştir. Araştırmacılar DKD’in düşük yağlı bir diyete göre vücut ağırlığı kaybı ve KVH risk faktörlerini azaltmada daha etkili olduğu sonucuna varmıştır. Bu etkinin muhtemel sebebinin de DKD’lerde dinlenme metabolik hızının ve total enerji harcamasının daha yüksek olması olarak belirtmişlerdir.

Tip 2 diyabetli 115 yetişkin obez bireyle yapılan başka bir çalışmada, katılımcılar 12 ay boyunca; düşük enerjili çok düşük karbonhidrat, düşük doymuş yağ (karbonhidrat: protein: yağ: doymuş yağ; \%14: \%28: \%58: <\%10 enerji) diyetine ve izokalorik bir yüksek karbonhidrat (karbonhidrat: protein: yağ: doymuş yağ; \%53: \%17:\%30: <\%10) diyetine randomize edilmiştir. Diyeti tamamlama oranı her iki grup da benzer oranlarda bulunmuştur. Vücut ağırlığı, HbA1c ve bozulmuş endotel fonksiyonu değerlendirilmiştir. Bir yılın sonunda her iki grupta da vücut ağırlığında $(-10.6 \pm 0.7 \mathrm{~kg})$ ve HbA1c düzeyinde $(-1.05 \pm 0.10)$ benzer oranlarda anlamlı bir azalma görülmüştür. 
Tablo 1. Düşük karbonhidratlı diyetler ve temel özellikleri (4)

\begin{tabular}{|c|c|c|}
\hline Diyet adı & Karbonhidrat İçeriği & Temel Özellikler \\
\hline Ketojenik & $<50$ g/gün & $\begin{array}{l}\text { Diyet, ana enerji kaynağı olarak keton cisimciklerin kullanımını } \\
\text { içermektedir. }\end{array}$ \\
\hline Atkins & $\begin{array}{l}\text { Başlangiç evresi: } 20 \text { g/ gün; } \\
\text { Sonraki aşamalar: } 80-100 \\
\text { g/gün }\end{array}$ & $\begin{array}{l}\text { Başlangıçta daha fazla karbonhidrat kısıtlaması içeren } 4 \text { evreden oluşur. } \\
\text { "Yeni Atkins” diyeti, fazla kilolu olanlar için başlangıç evresinde } 40 \text { g/gün } \\
\text { karbonhidrat seçeneği sunmaktadır. }\end{array}$ \\
\hline Eco-Atkins & 130 g/gün & $\begin{array}{l}\text { Enerjinin makro besin ögesi dağılımı \%26 karbonhidrat, \%31 protein, \%43 } \\
\text { yağ olan vegan diyettir. }\end{array}$ \\
\hline South Beach & $\begin{array}{l}\text { Evre 1: çoğu karbonhidratı } \\
\text { içermez. } \\
\text { Evre } 2 \text { ve } 3: \leq 140 \text { g/gün }\end{array}$ & $\begin{array}{l}\text { Atkins diyetinin artan doymuş yağ içeriği ile ilgili endişelere yanıt } \\
\text { olarak düzenlenmiştir. Karbonhidrat ve doymuş yağların kısıtlanmasını } \\
\text { vurgulamaktadır. Günde } 3 \text { ana ve } 3 \text { ara öğün içermektedir. }\end{array}$ \\
\hline Zone & \%40 karbonhidrat & $\begin{array}{l}\text { Diyetin makro besin ögesi dağılımı } \% 40 \text { karbonhidrat, } \% 30 \text { protein ve } \% 30 \\
\text { yağdan oluşmaktadır. Diyet günde } 7 \text { kez olmak üzere az miktarda, sık yemeyi } \\
\text { ve atıştırmalıkları vurgulamaktadır. }\end{array}$ \\
\hline Paleo & $\begin{array}{l}\text { Besin seçimlerine göre } \\
\text { değişir }\end{array}$ & $\begin{array}{l}\text { Et, balık, yumurta, sebze, meyve ve kuruyemiş gibi yiyeceklerle sınırlıdır. } \\
\text { Minimum seviyede kepekli tahıllar; işlenmiş besinler, ilave şeker, süt, } \\
\text { baklagiller, patates bulunmaktadır. }\end{array}$ \\
\hline $\begin{array}{l}\text { Dr. Bernstein's } \\
\text { Diabetes Solution }\end{array}$ & $30 \mathrm{~g} / \mathrm{gün}$ & $\begin{array}{l}\text { Kan glukoz düzeyinde hızlı yükselmeye neden olan yiyecekleri kısıtlayarak } \\
\text { glisemik indeksin önemini vurgulayan orijinal diyetlerden biridir. }\end{array}$ \\
\hline Sugar Busters & $\begin{array}{l}\text { Günde } 2-3 \text { porsiyon } \\
\text { karbonhidrat }\end{array}$ & $\begin{array}{l}\text { Rafine şeker ve beyaz un gibi glisemik indeksi yüksek besinleri sınırlayan } \\
\text { glisemik indekse dayalı bir diyet modelidir. }\end{array}$ \\
\hline LCHF & <20-100 g/gün & $\begin{array}{l}\text { Diyet yağlarının tokluk süresini uzatmasına dayalı olarak planlanan özellikte } \\
\text { İsveç’te yaygın olarak tercih edilen bir diyet modelidir. }\end{array}$ \\
\hline Protein Power & 28-40 g/gün & $\begin{array}{l}\text { Günde 4-5 öğün olarak yeterli protein ve sınırlı karbonhidrat alımını } \\
\text { vurgular. }\end{array}$ \\
\hline Sonoma & $\begin{array}{l}\text { Besin seçimlerine göre } \\
\text { değişir. }\end{array}$ & $\begin{array}{l}\text { Akdeniz ve düşük karbonhidratlı diyetleri birleştirir. Üç evre şeklinde } \\
\text { uygulanır. Doymuş yağ, nişasta ve şekeri en aza indirir. }\end{array}$ \\
\hline
\end{tabular}

LCHF: düşük karbonhidrat, yüksek yağ

Bozulmuş endotel fonksiyonunda başlangıca göre her iki grupta da anlamlı bir değişiklik gözlenmemiştir. Araştırmacılar çalışmada DKD’lerin doymuş yağdan fakir olduğu sürece endotel fonksiyon üzerine olumsuz etki yapmadığı sonuca varmıştır (28).

Randomize kontrollü 11 çalışmanın meta analizinin yapıldığı bir çalışmada, DKD ve düşük yağlı diyetlerin vücut ağırlığı kaybı ve KVH risk faktörleri üzerindeki etkileri değerlendirilmiştir. Toplam enerji alımının \%20'sinden azının karbonhidratlardan geldiği ve diyet müdahale süresi altı ay veya daha uzun olan çalışmalar meta analize dâhil edilmiştir. Düşük yağlı diyet grubundaki bireyler ile karşılaştırıldığında, DKD grubundaki bireylerin daha fazla vücut ağırlığı kaybı (-2.17 kg) sağladığı belirlenmiştir. Ayrıca HDL ve LDL kolesterolde daha fazla artış gözlenmiştir.
Düşük karbonhidratlı diyetlerin LDL kolesterol artışı ile olumsuz kardiyovasküler risk faktörüne yol açabileceği belirtilmiştir. Araştırmacılar bu yüzden uzun dönemde DKD’lerin mortalite ve morbiditeyi artırıp artıramayacağı üzerine daha fazla çalışma yapılması gerektiği sonucuna varmıştır (29).

$\mathrm{Hu}$ et al. (30) \%30'dan daha az yağ içeren diyetlere klyasla <\%45 karbonhidrat içeren diyetlerin etkileri üzerine randomize kontrollü klinik çalışmaların bir meta-analizini yapmıştır. Hem düşük karbonhidratlı hem de düşük yağlı diyetin, vücut ağırlığında azalma ve metabolik risk faktörlerinde iyileşme sağladığı belirlenmiştir. İki grup arasında vücut ağırlığı, bel çevresi ve metabolik risk faktörlerinin azalması açısından anlamlı bir farklılık gözlenmemiştir. Bu meta analizin sonucunda düşük karbonhidratlı ve 
az yağlı diyetlerin vücut ağırlığının azaltılması ve hastalıklara bağlı risk faktörleri üzerinde benzer etkileri olduğu belirtilmiştir.

Düşük karbonhidratlı yüksek yağlı diyet uygulamalarının, yüksek karbonhidratlı çalışmalarla karşılaştırıldığı sınırlı literatür bulunmaktadır. $\mathrm{Bu}$ diyetler karşılaştırıldığında vücut ağırlığı üzerindeki etkileri tutarlılık göstermemektedir. Düşük karbonhidratlı diyetlerin vücut ağırlığına ve metabolizmaya etkisinin tam olarak anlaşlabilmesi için enerji, karbonhidrat, yağ ve posa alımının vücut ağırlığındaki değişikliklerle birlikte değerlendirildiği, uzun süreli çalışmaların (en az iki yıl) yapılması gerekmektedir (31).

\section{SONUÇ VE ÖNERILER}

Son dönemlerde obezitenin artmasıyla birlikte zayıflamak için birçok diyet modeli gündeme gelmiş ve popüler olmuştur. Aralıklı açlık ve düşük karbonhidratlıdiyetlerbukapsamdayaygınuygulanan diyet modelleridir. Popüler diyetlerin güvenirliğinin anlaşılabilmesi için birçok çalışma yapılmaktadır ve daha fazlasinın da yapılması gerekmektedir. Bir diyetin başarılı olması için bireyin diyete uyumunun yüksek olması gerekir. Aralıklı açlık diyetlerinde açlık süresi uzadıkça diyete uyum azalmaktadır ve diyetin beslenme davranışı olarak devam ettirilmesi zorlaşmaktadır. Bunun birlikte aralıklı açlık diyetlerinden ADF ve TRF’nin vücut ağırlığı kaybı ve metabolizma üzerinde olumlu etkileri olduğu gözlenmiştir. Ancak ADF ve CR diyetinin birbirlerine üstünlükleri belirlenmemiştir. Ramazan orucundaki vücut ağırlığı kaybı azdır ve çoğunlukla geri kazanımı olmaktadır. Düşük karbonhidratlı diyetlerin, ağırlık kaybı ve metabolizma için olumlu sonuçları olsa da düşük yağlı diyetlerden daha etkili olup olmadığı konusunda çelişkili sonuçlar bulunmaktadır. Aralıklı açlık diyetleri ve DKD diyet modelleri hangi bireylere ve ne kadar süreyle uygulanabileceği, kısa ve uzun vadedeki etkileri, metabolik parametreler üzerine olumlu veya olumsuz etkileri iyi değerlendirilmelidir. Yapılan araştırmaların çoğu küçük örneklemli ve kısa süreli (<6 ay) izlem yapılan çalışmalardır. Bu diyetler kontrollü bir şekilde vücut ağırlık kaybı programlarının bir parçası olarak kullanılabilir ancak uzun dönemli etkilerinin daha iyi bir şekilde ortaya konulması için uzun süreli takip çalışmalarına ihtiyaç duyulmaktadir.

Çıkar çatışması - Conflict of interest: Yazarlar çıkar çatışması olmadığını beyan ederler. - The authors declare that they have no conflict of interest.

\section{KAYNAKLAR}

1. Fruh SM. Obesity: Risk factors, complications, and strategies for sustainable long-term weight management. J Am Assoc Nurse Pract. 2017;29(1):3-14.

2. Freire R. Scientific evidence of diets for weight loss: Different macronutrient composition, intermittent fasting and popular diets. Nutrition. 2020;69:110549.

3. Antoni R, Johnston KL, Collins AL. Robertson MD. Effects of intermittent fasting on glucose and lipid metabolism. Proc Nutr Soc. 2017;76(3):361-368.

4. Fields H, Ruddy B, Wallace MR, Shah A, Millstine D. Are low-carbohydrate diets safe and effective? J Am Osteopath Assoc. 2016;116:788-793.

5. Tinsley GM, La Bounty PM. Effects of intermittent fasting on body composition and clinical health markers in humans. Nutr Rev. 2015;73(10):661-674.

6. Patterson RE, Sears DD. Metabolic effects of intermittent fasting. Annu Rev Nutr. 2017;37:371-393.

7. Sözlü S, Şanlier N. Sirkadiyen ritim, sağllk ve beslenme ilişkisi. Turkiye Klinikleri J Health Sci. 2017;2(2):100-9.

8. Adamovich Y, Rousso-Noori L, Zwighaft Z, NeufeldCohen A, Golik M, Kraut-Cohen J, et al. Circadian clocks and feeding time regulate the oscillations and levels of hepatic triglycerides. Cell Metab. 2014;19(2):319-30.

9. Mortaş H. Vardiyalı çalışanlarda sirkadiyen ritim, bağırsak mikrobiyotası ve beslenme durumu arasındaki ilişkinin değerlendirilmesi [Doktora Tezi]. Gazi Üniversitesi Sağllk Bilimleri Enstitüsü, Ankara; 2019.

10. Trepanowski JF, Kroeger CM, Barnosky A, Klempel MC, Bhutani S, Hoddy KK, et al. Effect of alternateday fasting on weight loss, weight maintenance, and cardio protection among metabolically healthy obese adults: A randomized clinical trial. JAMA Intern Med. 2017;177(7):930-938.

11. Catenacci VA, Pan Z, Ostendorf D, Brannon S, Gozansky WS, Mattson MP et al. A randomized pilot study comparing zero-calorie alternate-day fasting to daily caloric restriction in adults with obesity. Obesity. 2016;24(9):1874-1883. 
12. Longo VD, Panda S. Fasting, circadian rhythms and time-restricted feeding in healthy lifespan. Cell Metab. 2016;23(6):1048-1059.

13. Akpınar Ş. Akbulut G. Aralıklı açlık diyetlerinin ağırlık denetimi ve sağlık çıktıları üzerindeki etkisi. SDÜ Sağlık Bilimleri Dergisi. 2019;10(2):177-183.

14. Rothschild J, Hoddy KK, Jambazian P, Varady KA. Time-restricted feeding and risk of metabolic disease: A review of human and animal studies. Nutr Rev. 2014;72(5):308-318.

15. Chung H, Chou W, Sears DD, Patterson RE, Webster NJ, Ellies LG. Time-restricted feeding improves insulin resistance and hepatic steatosis in a mouse model of postmenopausal obesity. Metabolism. 2016;65(12):17431754.

16. LeCheminant JD, Christenson E, Bailey BW, Tucker LA. Restricting night-time eating reduces daily energy intake in healthy young men: A short-term cross-over study. Br J Nutr. 2013;110(11):2108-13.

17. Chowdhury EA, Richardson JD, Tsintzas K, Thompson D, Betts JA. Effect of extended morning fasting upon ad libitum lunch intake and associated metabolic and hormonal responses in obese adults. Int J Obes. 2016;40(2):305-311.

18. Mindikoglu AL, Opekun AR, Gagan SK, Devaraj S. Impact of time-restricted feeding and dawn-to-sunset fasting on circadian rhythm, obesity, metabolic syndrome, and nonalcoholic fatty liver disease. Gastroenterol Res Pract. 2017;2017.

19. Rohin MAK, Rozano N, Abd Hadi N, Nor M, Nasir M, Abdullah S, et al. Anthropometry and body composition status during ramadan among higher institution learning centre staffs with different body weight status. Scientific World Journal. 2013;2013:308041.

20. Sadeghirad B, Motaghipisheh S, Kolahdooz F, Zahedi MJ, Haghdoost AA. Islamic fasting and weight loss: A systematic review and meta-analysis. Public Health Nutr. 2014;17(2):396-406.

21. Faris MAE, Madkour MI, Obaideen AK, Dalah EZ, Hasan HA, Radwan HM, et al. Effect of Ramadan diurnal fasting on visceral adiposity and serum adipokines in overweight and obese individuals. Diabetes Res Clin Pract. 2019;153:166-175.

22. Yeoh E, Zainudin SB, Loh WN, Chua CL, Fun S, Subramaniam T, et al. Fasting during Ramadan and associated changes in glycaemia, caloric intake and body composition with gender differences in Singapore. Ann Acad Med Singap. 2015;44(6):202-6.

23. Akpınar Ş, Akbulut G. Aralıklı açlık diyetlerinin ağırlık denetimi ve sağlık çıktıları üzerindeki etkisi. SDÜ Sağlık Bilimleri Dergisi, 2019;10(2):177-183.

24. Hajek P, Myers K, Dhanji AR, West O, McRobbie H. Weight change during and after Ramadan fasting. J Pub Health 2012; 34(3): 377-81.

25. Hu T, Bazzano LA. The low-carbohydrate diet and cardiovascular risk factors: Evidence from epidemiologic studies. Nutr Metab Cardiovasc Dis. 2014;24(4):337-343.

26. Sezer E. Düşük karbonhidratlı diyetler ve obezite. Turkiye Klinikleri J Nutr Diet-Special Topics. 2016;2(1):40-44.

27. Bazzano LA, Hu T, Reynolds K, Yao L, Bunol C, Liu Y et al. Effects of low-carbohydrate and low-fat diets: A randomized trial. Ann Intern Med. 2014;161(5):309-318.

28. Wycherley TP, Thompson CH, Buckley JD, LuscombeMarsh ND, Noakes M, Wittert GA et al. Long-term effects of weight loss with a very-low carbohydrate, low saturated fat diet on flow mediated dilatation in patients with type 2 diabetes: A randomised controlled trial. Atherosclerosis. 2016;252:28-31.

29. Mansoor N, Vinknes KJ, Veierød MB, Retterstøl K. Effects of low-carbohydrate diets v. low-fat diets on body weight and cardiovascular risk factors: A meta-analysis of randomised controlled trials. Br J Nutr. 2016;115(3):466479.

30. Hu T, Mills KT, Yao L, Demanelis K, Eloustaz M, Yancy WS, et al. Effects of low-carbohydrate diets versus lowfat diets on metabolic risk factors: A meta-analysis of randomized controlled clinical trials. Am J Epidemiol. 2012;176(7):44-54.

31. Brouns F. Overweight and diabetes prevention: Is a lowcarbohydrate-high-fat diet recommendable? Eur J Nutr. 2018;57(4):1301-1312. 